Omni-Akuatika, $16(1): 48-52,2020$
ISSN: 1858-3873 print / 2476-9347 online
Research Article
journal homepage: http://ojs.omniakuatika.net

\title{
Combination Cockle Shells (Anadara granosa) and Calcite Lime to Improve Swamp Water pH for Catfish (Pangasius sp.) Culture
}

\author{
Dade Jubaedah $^{{ }^{*}}$, Marsi ${ }^{2}$, Marini Wijayanti ${ }^{1}$, Sofiatul Rahmani ${ }^{1}$ \\ ${ }^{1}$ Study Program of Aquaculture, Department of Fisheries, Faculty of Agriculture, Sriwijaya University, INDONESIA \\ ${ }^{2}$ Study Program/Department of Soil Science, Faculty of Agriculture, Sriwijaya University, INDONESIA \\ "Corresponding author: dadejubaedah@fp.unsri.ac.id
}

Received 26 November 2018; Accepted 24 January 2020; Available online 31 May 2020

\begin{abstract}
Cockle shells was proven potential used as an alternative liming material. Combination of lime derived from cockle shells with calcite as common lime materials used to overcome limited quantity of cockle shells as the problem of seasonal availability of cockle shells. Besides, these materials have difference characteristics that to be expected can give better effect to $\mathrm{pH}$ of soil and water. This study aims to determine the best combination dose between cockle shell limes and calcite to increase the $\mathrm{pH}$ of water and soil, survival rate and growth of catfish (Pangasius sp.). The study used completely randomized design (CRD) with 5 treatments and 3 replications. The treatment of different combination of lime doses $100 \%$ calcite (P1), 100\% cockle shell limes (P2), $75 \%$ calcite and $25 \%$ cockle shell limes (P3), $50 \%$ calcite and 50\% cockle shell limes (P4), and 25\% calcite and 75\% cockle shell limes (P5), dose of lime used as much as $7,000 \mathrm{~kg} / \mathrm{ha} \mathrm{CaO}$ equivalent. The result showed that $\mathrm{P}_{4}$ was the best treatment according to data of swamp water $\mathrm{pH}$ was 8.13 and soil $\mathrm{pH}$ was 8.07 at final day (day 60), alkalinity 153.33 mg. $\mathrm{L}^{-1} \mathrm{CaCO}_{3}$ equivalent, $\mathrm{Ca} 104.15 \mathrm{mg} \cdot \mathrm{L}^{-1}, 100 \%$ survival rate, $11.23 \mathrm{~cm}$ absolute growth of length, $38.60 \mathrm{~g}$ absolute growth of weight and $128.38 \%$ feed efficiency.
\end{abstract}

Keywords: Calcite, Catfish, Cockle shells, Liming, Swamp

\begin{abstract}
ABSTRAK
Cangkang kerang terbukti potensial digunakan sebagai bahan pengapuran alternatif. Kombinasi kapur yang berasal dari cangkang kerang dengan kalsit sebagai bahan kapur biasa digunakan untuk mengatasi jumlah cangkang kerang yang terbatas sebagai masalah ketersediaan musiman cangkang kerang. Selain itu, bahan-bahan ini memiliki karakteristik yang berbeda sehingga diharapkan dapat memberikan efek yang lebih baik terhadap $\mathrm{pH}$ tanah dan air. Penelitian ini bertujuan untuk menentukan kombinasi dosis terbaik antara cangkang kerang dan kalsit untuk meningkatkan $\mathrm{pH}$ air dan tanah, tingkat kelangsungan hidup dan pertumbuhan ikan lele (Pangasius sp.). Penelitian ini menggunakan rancangan acak lengkap (RAL) dengan 5 perlakuan dan 3 ulangan. Perlakuan kombinasi yang berbeda dari dosis kapur $100 \%$ kalsit (P1), 100\% cangkang kerang (P2), kalsit 75\% dan $25 \%$ cangkang kerang (P3), kalsit $50 \%$ dan $50 \%$ kerang kerang (P4), dan $25 \%$ kalsit dan $75 \%$ limun kerang (P5), dosis kapur yang digunakan setara dengan $7.000 \mathrm{~kg} / \mathrm{ha} \mathrm{CaO}$. Hasil penelitian menunjukkan bahwa P4 adalah perlakuan terbaik menurut data $\mathrm{pH}$ air rawa adalah 8,13 dan $\mathrm{pH}$ tanah 8,07 pada hari terakhir (hari 60), alkalinitas setara $153,33 \mathrm{mg} \cdot \mathrm{L}^{-1} \mathrm{CaCO}_{3}$, tingkat kelangsungan hidup $\mathrm{Ca} 104,15 \mathrm{mg} \cdot \mathrm{L}^{-1} .100 \%, 11,23 \mathrm{~cm}$ pertumbuhan panjang absolut, 38,60 g pertumbuhan berat absolut, dan efisiensi pakan $128,38 \%$.
\end{abstract}

Kata Kunci: kalsit, lele, cangkang kerang, pengapuran, rawa

\section{Introduction}

Liming of soil is an effort to increase soil and waters $\mathrm{pH}$ of swamp fish ponds. Ponds can be limed with liquid lime, basic slag, or agricultural limestone (Wynne 1996; Boyd 1982, 1990; Wilkinson 2002). Common liming materials 
include agricultural limestone and liquid lime, calcium hydroxide, calcium oxide and basic slag. Peters (1996) described liming materials that was commonly used are calcitic aglime, dolomitic aglime, hydrated or slaked lime, quicklime or burnt lime, marl, and industrial by product.

An alternative liming material from domestic waste or by-product have an advantage, not only increase $\mathrm{pH}$ level, but also environmentally acceptable. The research showed that cockle shells (Anadara granosa) can be used to increase soil and water's pH of swamp fish ponds (Jubaedah et al. 2017). Initial soil's pH value from 3.9 increase to 7.2 as affected by 5 ton/ha lime derived from cockle shells application during 7 days incubation time and maximal water's $\mathrm{pH}$ value 7.9 at day 87 . Next lime application should be considered after day 205.

According Wilkinson (2002), acid sulfate soils within a pond or its watershed must therefore be treated if the pond is to be used for production. However, large amounts of lime are typically required and the technique may not be economically feasible. Seasonal availability of cockle shells needs to combine with common agriculture limestone.

Calcite (Calcium carbonates, $\mathrm{CaCO}_{3}$ ) is one kind of agricultural lime stone that slowly react but simultaneously safe to fish (Boyd, 1982; 1990) Calcium carbonates on cockle shells converted to calcium oxide through calcination process. $\mathrm{CaO}$ short-term acting but can be unsafe for fish (Nobre et al. 2014). The present work aimed to compare the $\mathrm{pH}$ of soil and water as well as survival rate and growth performance of catfish juvenile reared in ponds with application of combination of combination of calcite $\left(\mathrm{CaCO}_{3}\right)$ and lime derived from cockle shells.

\section{Materials and Methods}

\subsection{Preparing Lime Materials and Liming} Application

Calcination process of $A$. granosa shells according to Jubaedah et al. (2017), including burning process using furnace at temperature of $800^{\circ} \mathrm{C}$ for an hour. The calcin then mashed and sieved with 60,40 and 20 mesh-size sieves in order to get lime with $50 \%$ passed 60 mesh-size sieve, $25 \%$ passed 40 mesh-sized sieve, and 25 $\%$ passed 20 mesh-size sieve.

Five combination of lime were investigated, namely: P1) $100 \%$ calcite, P2) $100 \%$ cockle shells lime, P3) $75 \%$ calcite and $25 \%$ cockle shell limes, P4) 50\% calcite and 50\% cockle shell limes, and P5) $25 \%$ calcite and $75 \%$ cockle shell limes, dose of lime each used as much $7,000 \mathrm{~kg} / \mathrm{ha} \mathrm{CaO}$ equivalent. Lime were applied homogeneously on soil ponds and incubated for 7 days at field capacity soil moisture. Water was filled to the ponds and and let equilibrated for 3 days. Fish stocked on ponds and cultured for 60 days.

\subsection{Fish Culture}

Fifteen unit of fish ponds filled swamp water with $500 \mathrm{~L} /$ ponds at 7 days after liming. Fish were acclimatized for one week before used in this research. The fifteens of $5 \pm 0.5 \mathrm{~cm}$ length Pangasius sp. stocked for each pond.

Starting from 10 days after liming, fish was cultured for 60 days. The fish were fed to satiation three times per day with an artificial diet containing $30 \%$ protein. Water samples were collected and analyzed, as well as growth of fish was measured every 20 days.

\subsection{Experimental variables and analytical procedures}

Water quality, survival and growth performance variables were observed in the present work. The water's $\mathrm{pH}$, total alkalinity, and total ammonia were monitored every 20day, Ca concentration analyzed every 30 days in all pond. Besides, water temperature and $\mathrm{pH}$ were recorded daily. The water $\mathrm{pH}$ was measured by using a portable $\mathrm{pH}$ meter. The water temperature was observed by using a digital handy thermometer. The analytical determinations of total alkalinity and total ammonia and $\mathrm{Ca}$ were carried out according to the guidelines presented by APHA (2012). The fish initial and final body weight and length, survival and feed efficiency were observed in all experimental units.

Water quality, survival and growth performance results were statistically analyzed according to the two-way Anova to detect if there was any significant influence due to experimental treatments. When the influence was at least significant, the means were compared using Least Significant Difference (LSD) test.

\subsection{Data Analysis}

The fish survival rate was calculated from the initial number of fish and mortality after the experiment was completed. The absolute growth of fish was determined from the mean of initial and final weight and length of fish, respectively for absolute weight growth and length growth. Meanwhile, feed efficiency was calculated by the formula of NRC (1977). 


\section{Results and Discussion}

The initial Soil pH used in this current study was 3.60 and then soil $\mathrm{pH}$ increased due to liming to $\mathrm{pH} 7.40-7.53$ after incubated for 7 days (Figure 1). The soil's $\mathrm{pH}$ tends to increase rapidly until neutral $\mathrm{pH}$ value at the beginning of incubation, then increase slowly.

Regression between combination of limes and $\mathrm{pH}$ of soil and water showed polynomial quadratic patterns for day $0,10,20$ and 30 (Figure 2 and Figure 3 ). The results showed combination of calcite (50\%) and cockle shells lime $(50 \%)$ has highest soil's and water's $\mathrm{pH}$. The calcination process of cockle shells converts calcium carbonate $\left(\mathrm{CaCO}_{3}\right)$ to calcium oxide (CaO). According to Boyd (1982; 1990), reaction with acidity is faster than $\mathrm{CaCO}_{3}$, but highly caustic and cause the water $\mathrm{pH}$ raise to levels toxic for fish. Calcite $\left(\mathrm{CaCO}_{3}\right)$ is agricultural limestone that is slow-acting product but generally the safest (Boyd 1982; Nobre et al. 2014). The combination of cockle shells lime and calcite raise $\mathrm{pH}$ value higher than single lime, both cockle shells and calcite.

The initial water $\mathrm{pH}$ used in this research was 3.5 , then water $\mathrm{pH}$ increased following polynomial quadratic patterns for 60 days of fish culture due to lime application (Figure 4). According to equations shown in Figure 3, the maximum $\mathrm{pH}$ and days after lime application to

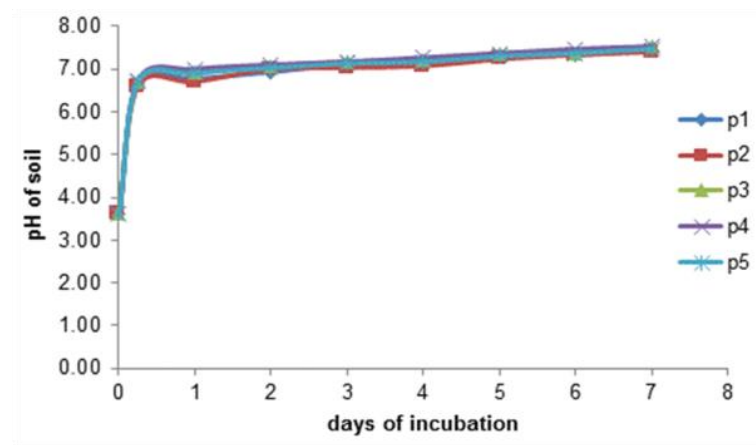

Figure 1. Soil's pH at 7 days of incubation
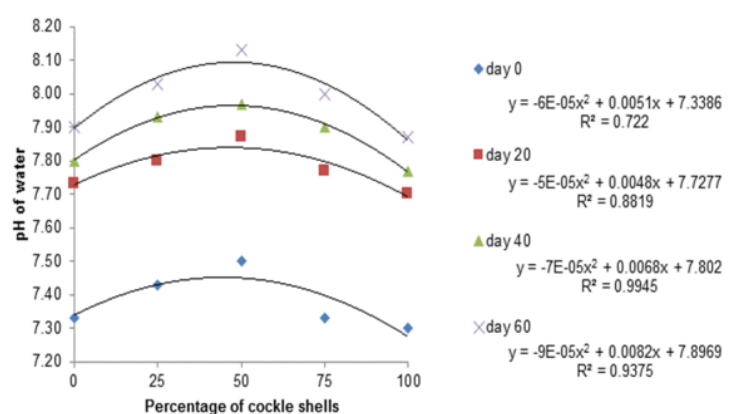

Figure 3. Relationship between combination of cockle shells and calcite and $\mathrm{pH}$ of water reach maximum water $\mathrm{pH}$ can be calculated. The maximum water $\mathrm{pH}$ and when it is were 7.85 at 50 days after liming, 7.82 at 50 days after liming, 7.93 at 50 days after liming, 8.31 at 89 days after liming and 8.03 at 59 days after liming, respectively for $\mathrm{P} 1, \mathrm{P} 2, \mathrm{P} 3, \mathrm{P} 4$ and $\mathrm{P} 5$.

The highest maximum water $\mathrm{pH}$ among treatments was observed on $\mathrm{P}_{4}(50 \%$ calcite and $50 \%$ cockle shell lime). Furthermore, based on the equations (Figure 4) and minimum water $\mathrm{pH}$ (6.5) for optimal growth of Pangasius sp., the next lime application should be considered after day, $132^{\text {th }}, 132^{\text {th }}, 134^{\text {th }}, 224^{\text {th }}$ and $146^{\text {th }}$ for $\mathrm{P} 1$, P2, P3, P4 and P5, respectively.

Liming not only increase $\mathrm{pH}$ value, but also alkalinity of water. Based on Figure 5 showed that liming application of combination cockle shell limes and calcite affected to increase alkalinity of water. Greater alkalinity after liming also buffer water from drastic daily changes in $\mathrm{pH}$ (Boyd, 1990).

Liming also related to calcium (Ca) concentration. Fish will lose $\mathrm{Ca}$ to the water on extremely low $\mathrm{Ca}$ concentration in the water, even though the minimum acceptable $\mathrm{Ca}$ concentration in the water necessary to permit optimum fish growth has not been established (Boyd, 1990). The liming was giving significantly different to $\mathrm{Ca}$ concentration at final day of research (day $60^{\text {th }}$ ) (Table 1 ). Combination of cockle shell lime $50 \%$ and calcite $50 \%$ (P4) has

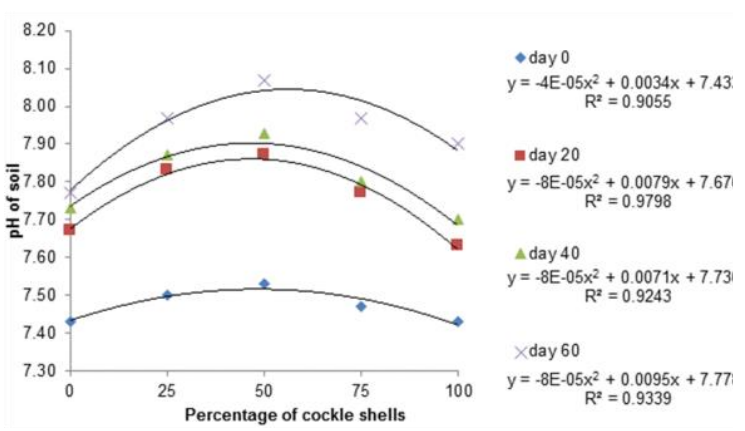

Figure 2. Relationship between combination of cockle shells and calcite and $\mathrm{pH}$ of soil

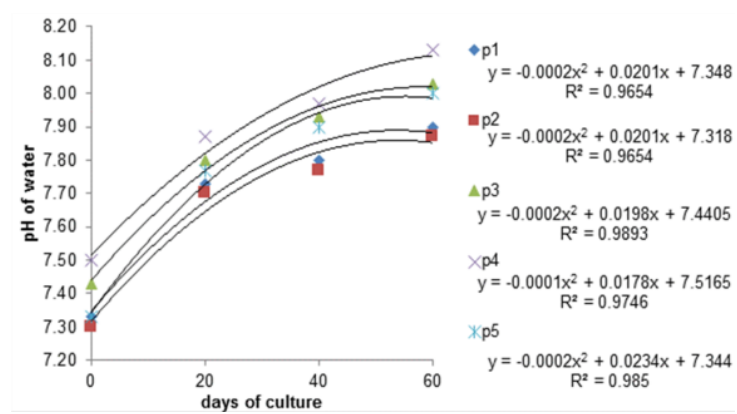

Figure 4. Relationship between days of culture and $\mathrm{pH}$ of water for each treatment 


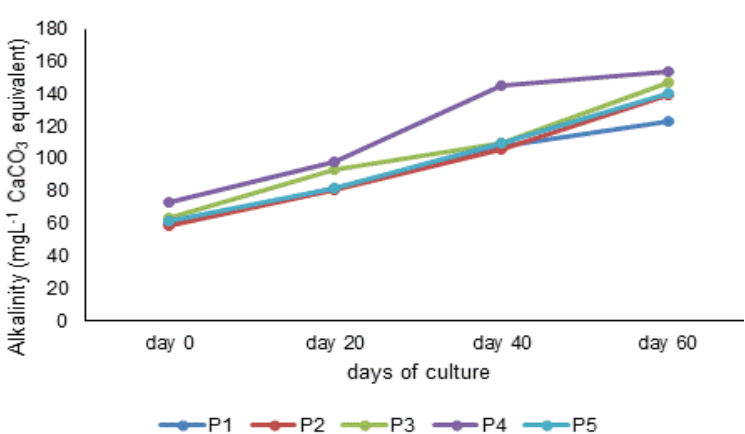

Figure 5. Alkalinity for each treatment

highest $\mathrm{Ca}$, significance different with calcite $100 \%$ (P1) and cockle shell 100\% (P2), but no significant different with combination cockle shell lime $75 \%$ calcite and $25 \%$ cockle shell limes (P3), and $25 \%$ calcite and $75 \%$ cockle shell limes (P5). According to Boyd et al. (2002), Ca concentration from calcite is $40.08 \%$, meanwhile based on the analysis of $\mathrm{Ca}$ content from cockle shells is $61.16 \%$.

The water temperature and dissolved oxygen (DO) of ponds (Table 2) ranged from 25.3 to $32.2{ }^{\circ} \mathrm{C}$ and from 5.4 to $6.6 \mathrm{mg} \cdot \mathrm{L}^{-1}$, respectively. Based on National standardization Agency or Badan Standar Nasional Indonesia (BSNI, 2000), the temperature of water was exceed optimum ranged that is $27-30^{\circ} \mathrm{C}$ according to optimal value of temperature for Pangasius sp. but still in tolerance ranged for fish. Meanwhile, the DO was approriate for Pangasius sp. No significant effect of lime application on dissolved oxygen at day $0,20,40$, and 60 of the rearing period.

Table 1. Concentration of $\mathrm{Ca}$ in water

\begin{tabular}{crrr}
\hline \multirow{2}{*}{ Treatment } & \multicolumn{3}{c}{ Concentration of $\mathrm{Ca}\left(\mathrm{mg}^{\mathrm{L}} \mathrm{L}^{-1}\right)$} \\
\cline { 2 - 4 } & day 0 & day 30 & \multicolumn{1}{c}{ day 60} \\
\hline P1 & 45.77 & 68.70 & $69.69_{\mathrm{a}}$ \\
P2 & 45.27 & 71.23 & $69.70_{\mathrm{a}}$ \\
P3 & 53.70 & 74.07 & $101.32_{\mathrm{b}}$ \\
P4 & 56.53 & 76.33 & $104.15_{\mathrm{b}}$ \\
P5 & 48.93 & 72.33 & $79.61_{\mathrm{ab}}$ \\
\hline LSD $_{0.05}$ & & & 24.97 \\
\hline
\end{tabular}

Number with subscribe different letters in column are significantly different by the LSD test $(p<0.05)$. No letters mean not significant ( $p>0.05)$.

Table 2. The water temperature and dissolved oxygen (DO)

\begin{tabular}{crcccc}
\multirow{2}{*}{ Treatment } & \multirow{2}{*}{ Temp. $\left({ }^{\circ} \mathrm{C}\right)$} & \multicolumn{4}{c}{$\mathrm{DO}\left(\mathrm{mg}^{\mathrm{L}} \mathrm{L}^{-1}\right)$} \\
\cline { 3 - 6 } & & day 0 & day 20 & day 40 & day 60 \\
\hline P1 & $25.3-31.8$ & 5.7 & 6.3 & 6.6 & 6.6 \\
P2 & $25.5-32.0$ & 5.5 & 6.0 & 6.6 & 6.6 \\
P3 & $25.6-32.1$ & 5.6 & 5.9 & 6.5 & 6.4 \\
P4 & $25.4-32.2$ & 5.6 & 5.9 & 6.5 & 6.6 \\
P5 & $25.4-32.2$ & 5.4 & 6.0 & 6.3 & 6.5 \\
\hline
\end{tabular}

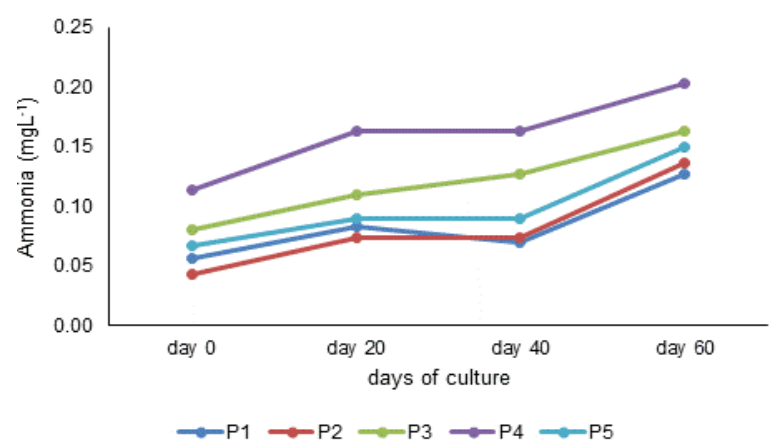

Figure 6. Ammonia concentration

All treatment showed that the ammonia concentration increased in the final day of research (day $60^{\text {th }}$ of culture) (Figure 6). The ammonia concentration at culture periods under maximal value for amonia for fish according to Indonesian environmental regulation or Peraturan Pemerintah Republik Indonesia (2001) that is $>1 \mathrm{mg} \cdot \mathrm{L}^{-1}$.

The survival rate of Pangsius sp. Were $100 \%$ for all treatments. The liming application using single lime materials both calcite $100 \%$ and cockle shells $100 \%$, or combination of them can increase $\mathrm{pH}$ until optimum for fish. In general, the water quality supported for living of fish.

The growth performance and fed efficiency showed at Table 3 Based on analysis of variance showed that treatment gave an effect to growth performance of fish. The highest absolute growth (length and weight) of fishes was on combination $50 \%$ cockle shells and $50 \%$ calcite $\left(\mathrm{P}_{4}\right)$ and significant difference with others.

The highest feed efficiency was on fish cultured at ponds with liming combination calcite $(50 \%)$ and cockle shells $(50 \%)$. It is probably related to availability of plankton as natural feed of fish. The highest alkalinity shown at P4 (Figure 5) and it will increase the carbon dioxide for photosynthesis of phytoplankton. According to Boyd (1982, 1990) and Wilkinson (2002), the positive effect of liming was increasing the alkalinity of water, thereby increasing the

Table 3. Growth performance and feed efficiency

\begin{tabular}{|c|c|c|c|}
\hline \multirow[b]{2}{*}{ Treatments } & \multicolumn{2}{|c|}{ Absolute growth of } & \multirow{2}{*}{$\begin{array}{c}\text { Feed } \\
\text { efficiency } \\
(\%)\end{array}$} \\
\hline & $\begin{array}{l}\text { Length } \\
(\mathrm{cm})\end{array}$ & $\begin{array}{l}\text { Weight } \\
\text { (g) }\end{array}$ & \\
\hline $\mathrm{P} 1$ & $10.00_{a b}$ & $28.67 a$ & 91.88 \\
\hline P2 & $9.74 a$ & $29.31_{a b}$ & 99.98 \\
\hline P3 & $10.48 b$ & $32.08_{c}$ & 96.96 \\
\hline P4 & $11.23_{c}$ & $38.60_{d}$ & 128.38 \\
\hline P5 & $9.94 \mathrm{ab}$ & $31.36 \mathrm{bc}$ & 94.57 \\
\hline $\mathrm{LSD}_{0.05}$ & 0.61 & 2.18 & \\
\hline
\end{tabular}

Number with subscribe different letters in column are significantly different by the $L S D$ test $(p<0.05)$. No letters mean not significant $(p>0.05)$. 
availability of carbon dioxide for phytoplankton growth. Wilkinson (2002), from some references conclude that applying lime has been shown to increase soluble phosphorus concentrations as nutrient of phytoplankton. Lime provides calcium and neutralizes acidic soils so that phosphate is released as calcium exchanges with aluminum and iron. Calcium phosphates are more soluble in water than aluminum phosphates or iron phosphates (Burtle, 2015).

\section{Conclusion}

The combination of $50 \%$ cockle shells lime and $50 \%$ calcite was the best treatments with $\mathrm{pH}$ of soil and water at day 60 were 8.07 and 8.31 , respectively; highest maximal water $\mathrm{pH}$ value (3.31) and next liming was at day 224; highest alkalinity (153.33 mg. $\mathrm{L}^{-1} \mathrm{CaCO}_{3}$ equivalent), and $\mathrm{Ca}\left(104.15 \mathrm{mg} \cdot \mathrm{L}^{-1}\right)$; highest feed efficiency (128.38\%); and the best growth performance. The water quality including water temperature, dissolved oxygen and ammonia were in appropriate for Pangasius sp. with $100 \%$ survival rate.

\section{References}

APHA (American Public Health Association). 2012. Standard Methods for the Examination of Water and Wastewater, 22nd Edition. American Water Works, Washington D.C. 541 pp.

BSNI (Badan Standar Nasional Indonesia). 2000. Produksi benih ikan patin siam (Pangasius hypopthalmus) kelas benih sebar. Jakarta. $13 \mathrm{pp}$.

Boyd, C.E. 1982. Water Quality Management for Pond Fish Culture. Elsevier Scientific Publishing Company: 119-154

Boyd, C.E. 1990. Water Quality in Ponds fo Aquaculture. Alabama Agricultural
Experiment Station, Auburn Unversity: 482pp.

Boyd, C. E., Boonyaratpalin, M., Thunjai T. 2002. Properties of liming materials. Aquaculture Asia 7: 7-8.

Burtle, G.J. 2015. Pond fertilization and liming in Georgia. University of Georgia College of Agricultural Environmental Sciences, Athens.

Jubaedah, D., Marsi., Rizki, R. R. 2017. Utilization of Anadara granosa as a liming materials for swamp fish ponds for Pangasius $s p$ culture. Aquacultura Indonesia 18(2): 48-54.

Nobre, M. K. B., Lima, F. R. D. S., Magalhães, F. B., Sá, M.V. D. C. E. 2014. Alternative liming blends for fish culture. Acta Scientiarum. Animal Sciences 36(1): 1-11.

NRC (National Research Council). 1977. Nutrient Requirements of Warmwater Fishes. Washington DC: National Academy Press.

Peraturan Pemerintah Republik Indonesia, Nomor. 82 Tahun 2001. Pengelolaan Kualitas Air dan Pengendalian Pencemaran Air. Jakarta.

Peters, J. B. , Kelling, K. A., and Schulte, E. E. 1996. Choosing Between Liming Materials. University of Wisconsin: 1-4.

Wilkinson, S. 2002. The use of lime, gypsum, alum and potassium permanganate in water quality management. Aquaculture Asia: 12-14.

Wynne, F. 1996. The use of Agricultural Limestone and Gypsum in Ponds. 8th Triennial National Wildlifw \& Fisheries Extension Specialis Conference. University of Nebraska-Lincoln. 